\title{
The Relationship between Organizational Structure and Organizational Culture with Teacher Performance in Pesantren
}

\author{
Djamaluddin Perawironegoro \\ Postgraduate of Islamic Education \\ Universitas Ahmad Dahlan \\ Yogyakarta \\ djamaluddin@mpai.uad.ac.id
}

\begin{abstract}
The purpose of this research is to explain the relationship between organizational structure, and organizational culture with teacher performance in Pesantren institution as an indigenous educational institution in Indonesia. Both become prediction to increase teacher performance. This research used a quantitative approach with the correlation model. While the population from this study is teachers at Pesantren in Depok City West Java. The finding is there is a correlation between the organizational structure with teacher performance is 0.683 , and organizational culture with teacher performance is 0.749 . When both variables are together correlated by teacher performance result is $\mathbf{0 . 7 6 4}$, and contribute to $58,4 \%$ to teacher performance. It is found that significant relationship between organizational structure and organizational culture to teacher performance in Pesantren education system. The implication is with high levels of organizational structure, and strong organizational culture will make high teacher performance. So the leaders and managers at Pesantren have to manage these two variables that might increase teacher performance.
\end{abstract}

Keywords- Organizational structure, organizational culture, teacher performance, Pesantren

\section{INTRODUCTION}

Teacher profession as stated in National Education System law number 20 on 2003 mentioned that Educators are qualified teaching staff as teachers, lecturers, counselors, and others. Then clarified by law number 14 on 2005 about teacher and lecture, described that teachers are professional educators with the main task of educating, teaching, guiding, directing, training, evaluating, and evaluating students in early childhood education through formal education, basic education and secondary education.

The law expresses clearly the work of the teacher which consists of educating, teaching, guiding, directing, training, evaluating, and evaluating students in the formal education level. The results of their work are called teacher performance. Bernardin and Russel (1993) stated that the performance is the record of producing a specified job function or activity during a specified job function or activity during a specified time period.

Measuring teacher performance is an important task for the educational institutions. With performance measurement, the principals and school manager will know the level of achievement of the tasks assigned to the teacher. On the one side, when teacher performance is high, managers will increase the effectiveness of achieving goals that will be realized. On the other side, when doing the low performance is to do an evaluation to find out the factors that lead to low performance.

Various approaches are taken to measure teacher performance. In performance measurement, some teachers get high performance, but some teachers have low performance. In general, the degree of teacher performance predicted by motivational factors. Low teacher motivation has implications for low teacher performance, whereas high motivation implies high performance.

In this study, the researcher examined the predictions for teacher performance by use organizational system factors. Organizational structure and organizational culture is a part of the organizational system. The organizational system here is intended to be the organizational structure and organizational culture, as stated by Robbins and Judge (2007).

The empirical study conducted by Hutabarat (2015) in the resulted is findings that organizational structure and organizational culture affect the work motivation of the teacher directly. The other result study, there is a conclusion that the organizational structure had a significant influence on the performance of high school teachers in Medan. Another researcher such as Ate (2014), Raza et.al (2010), Koesmono (2005), Arifin et.al (2014) described that organizational culture has a positive and significant relationship to teacher performance.

Various studies reveal theoretically and empirically that there is a relationship between organizational structure and organizational culture with teacher performance. In this study the theory will be tested on Pesantren teachers, the research performed on Pesantren teachers with the assumption that Pesantren teachers have similarity with teacher in school, it means that they have not different with school teachers in general task of educating. In addition, the current trend in education is to study at Pesantren. Indonesian people, especially the muslim parent still believe that education in Pesantren has an advantage about internalizing Islamic character among the student. 


\section{THEORETICAL FRAMEWORK}

\section{A. Organizational Structure}

The structure is an important part of the organization. The importance of understanding the organizational structure is because it is one of the sub-systems of management as a system. Robbins $(2007 ; 425)$ revealed that the organizational structure is how jobs are formally divided, grouped, and coordinated. Usman (2011) mentioned the formal system of the relationship between rules and tasks and the interconnected authority that controls how people work together and utilize resources to achieve organizational goals. An organizational working mechanism that describes its work units with individual tasks in it and their cooperation with other individuals vertically and horizontally (Pidarta; 2011).

The working mechanism here is intended to be a formulation of tasks that must be done in the organization in groups into work units. Then the work is distributed to the personnel in the unit according to their respective competencies.

From some definitions and instructions above, can be understood that the organizational structure is a grouping of employees into tasks in which the parts have a formal relationship, coordination, and communication to achieve organizational goals.

The relationship between organizational structure and performance is expressed by Robbins and Judge (2007) which states that the specific effect of structural designs on performance and satisfaction is moderated by employees' individual preferences and cultural norms. The organizational structure influences work performance and satisfaction. These influences are moderated by choices favored by individuals and cultural norms. Colquitt et.all (2009) stated that structure affects communication patterns between employees, the tasks of an employee performance. The empirical study, described by Hutabarat (2015) the findings result are the organizational structure had a significant effect on the teacher performance of high school teachers in Medan North Sumatra.

\section{B. Organizational Culture}

Robbins and Judge (2007) describe organizational culture as a system of shared meaning held by members of the organization from other organizations. The important characteristics of culture are innovation and risk tolerance, attention to detail, orientation to results, orientation towards the internal organization, group orientation, aggressiveness, and stability. Daft $(2007,239)$ revealed the set of values, norms, guiding beliefs, and understandings are shared by members of an organization and is taught to new members.

From the concepts mentioned above, it can be concluded that organizational culture is values, norms, which are shared by the organization to determine how the behavior of the members of the organization acts to achieve organizational goals. School culture is something built from the results of the meeting between the values held by the principal as a leader and the values held by the teachers and employees in the school. (Muhaimin et.all; 2011, 48).
In this study, organizational culture is defined as values, norms, which are shared by the organization to determine how the behavior of members of the organization acts to achieve organizational goals. While the indicators of organizational culture in this study are socialization of organizational value, regular ways of acting, prioritizing organizational goals, following applicable regulations, views of life, exchanging information among members.

Some theoretical studies reveal the relationship between organizational culture and employee performance. Daft (2007; 250) mentions that the right culture can drive high performance. Gibson et.al (2009; 33) mentions since organizational culture involves shared expectations, values, and attitudes. It exerts influence on individuals, groups, and organizational processes. Robbins and Judge (2007; 533) said that employees form an overall subjective perception of the organization based on factors such as the degree of risk tolerance, team emphasis, and support of people. This overall perception becomes, in effect, the organization's culture or personality. Suharsaputra $(2013 ; 111)$ cites the opinions from Lunenburg and Ornstein (2004) stating that organizational culture influences employee performance.

Empirically, the study of the relationship between organizational culture and teacher performance has conducted by Hutabarat (2015) explains that organizational culture influences work motivation, job satisfaction, and performance sequentially and significantly. Raza et al (2010) on his research found that organizational climate has a significant correlation to teacher performance. It was also explained that an open organizational climate has a more positive correlation with teacher performance than for a patterned and closed organizational climate. Koesmono (2005) explains that organizational culture influences employee performance, while also influencing work motivation and job satisfaction. Arifin et.al (2014) in his research concluded that organizational culture and transformational leadership also have a positive and significant relationship to teacher performance. Ate (2014) shows that the school organizational culture is defined by lived core values and grow by the founders, leaders, and principals. So organizational culture influences teacher performance in school. Susilo and Supardjo (2014) in their research found that organizational culture has a positive and significant influence on job satisfaction, performance, motivation, teacher's pedagogic competencies, and principals' behavior.

\section{Teacher Performance}

Performance is the result of evaluating the work done by comparing the work results with the criteria that have been set together. There are several factors that influence a person's performance.

The most common thing founded for evaluating the organization is about job performance. Colquitt et all. (2009; 37) said that job performance is formally defined as the value of the set of employee behaviors that contribute, either positively or negatively, to organizational goal accomplishment. Judge and Robbins (2007: 553) provide an overview to evaluate or provide a performance assessment centered on three criteria individual task outcomes, behaviors, 
and traits. Performance reveals the achievement of the list of tasks that have been done (Usman, 2011; 489).

The indicators for teacher performance ss described by Usman (2011) there are five factors in measuring performance; 1) quality of work; 2) quantity of work, 3) Supervision required; 4) presence; 5) conservation. Mathis and Jackson (2004) give another focus not only in work, but also in result: 1) quantity of results; 2) quality of results; 3) timeliness of results; 4) attendance; and 5) ability to cooperate.

With the performance appraisal being carried out periodically, it is expected that the teachers will be able to know the strengths and weaknesses they have, and then become a reference for future performance improvements. For measuring teacher performance, it is necessary to determine indicators that show teacher performance.

The relation between organizational culture and organizational structure with teacher performance, Colquitt et. all (2009; 514) stated that organizational mechanisms consisting of culture and organizational structure are related to individual mechanisms which ultimately return to individual efforts in the form of performance. As described above theoretically and empirically organizational culture and organizational structure have the correlation to individual performance. This means that the organizational structure provides an opportunity for someone to act as the authority and duties. In the end, each individual carries out their respective duties and results in dynamic and innovative organizational movements.

From the descriptions above, it can be assumed that there is a positive relationship between organizational culture and organizational structure simultaneously with teacher performance.

\section{RESEARCH METHOD}

This research is quantitative research, the type used in this study is correlation research. This research was carried out in Pesantren throughout Depok City which according to Ministry of Religion data there were 63 Islamic Boarding Schools with a population of 850 Pesantren teachers. From this population researchers took 6 Pesantren with the total number of teachers, 230 teachers. The sample in this study was 123 respondents, which was determined by the calculation method of Isaac and Michael for a level of error of $10 \%$.

In this research organizational structure indicators for this research are; 1) task clarity, 2) work relationships, 3) assignments to subordinates, 4) procedures for doing tasks, 5) helping each other, and 6) delegating.

While the indicators of organizational culture in this study are 1) socialization, 2) regular ways of acting, 3) prioritizing organizational goals, 4) following applicable regulations, 4) views of life, and 5) exchanging information among members.

Teacher performance indicators consist of two dimensions, the process dimension, and behavior dimensions. Included in the process dimensions process are: 1) making teaching planning, 2) classroom management, 3) applying appropriate methods and media, 4) conducting guidance and counseling, 5) conducting evaluations, while including behavioral dimensions including 1) timeliness of teaching, 2) appearance at the time of teaching in class, 3) cooperation, 4) obeying the rules of the school or madrasah, and 5) maintaining behavior in the community.

The data collected by questionnaire method which is carried out by distributing a list of statements to all respondents. Questionnaire in this research used a Likert scale. The data obtained were analyzed in two ways, the first is a descriptive statistical, and the second is inferential statistics which used to analyze data for fulfilling hypothesis test.

\section{RESEARCH RESULT AND DISCUSSION}

\section{A. Descriptive Analysis Research}

After doing the research, Table 1 are the results of the data processed by descriptive analysis which includes the minimum value, the maximum value, mean, and standard deviation of the variables of organizational structure, organizational culture, and the teacher performance. Thus it provides a descriptive description of the data collected from respondents.

TABLE I. DESCRIPTIVE DATA SUMMARY

\begin{tabular}{|c|r|r|r|r|r|}
\hline Var. & \multicolumn{1}{|c|}{ N } & \multicolumn{1}{|c|}{ Min. } & Max. & \multicolumn{1}{c|}{ Mean } & $\begin{array}{c}\text { Std. } \\
\text { Deviation }\end{array}$ \\
\hline Org. Structure & 123 & 67 & 106 & 89.15 & 7.892 \\
\hline Org. Culture & 123 & 71 & 112 & 93.61 & 9.690 \\
\hline Teacher Performance & 123 & 71 & 108 & 92.21 & 8.693 \\
\hline
\end{tabular}

Based data in Table 1, can be explained that organizational structure gets an average (mean) value 89.15 with deviation standard 7.892. Organizational culture gets average 93.61 with deviation standard 9.690. and teacher performance gets 92.21 with deviation standard 8.693.

\section{B. Inferential Analysis Research}

The first hypothesis is there is correlation between organizational structure with teacher performance in Pesantren.

TABLE II. CORRELATIONS

\begin{tabular}{|c|r|r|r|}
\hline & & $\begin{array}{c}\text { Teacher } \\
\text { Performance }\end{array}$ & $\begin{array}{r}\text { Org. } \\
\text { Structure }\end{array}$ \\
\hline Teacher Performance & Pearson Correlation & 1 & $.683(* *)$ \\
Org. Structure & Sig. (2-tailed) &. & .000 \\
& Pearson Correlation & $.683(* *)$ & 1 \\
& Sig. (2-tailed) & .000 &. \\
\hline
\end{tabular}

** Correlation is significant at the 0.01 level (2-tailed).

From the table 2 show the strong relationship between teacher performance and organizational cultural variables, it can be seen that the Pearson correlation coefficient number is $.683 * *$. This means that the correlation is 0.683 or a strong correlation because it near to the number 1 . Another mean of this correlation is the correlation was in positive, were the positive correlation mean when the organizational structure high the teacher performance will be high. The two-star sign (**) means that the correlation is significant at 0.01 and has a two-way (2-tailed) possibility. 
The relationship between these two variables shown by the result of correlation is 0.000 that smaller than $0.001(0.000<$ $0.001)$. It's mean that the relationship between these variables is significant. Other values have two way (2-tailed), it's mean can be unidirectional or unidirectional. Thus reject the null hypothesis and accept alternative hypothesis, it's meaning there is a significant relationship between organizational structure and teacher performance in Pesantren.

The determination coefficient functions is to determine the percentage of the strongest independent variable to dependent variable. In this case the organizational structure to teacher performance as shown in table 3 :

TABLE III. MODEL SUMMARY (B)

\begin{tabular}{|c|c|c|c|c|}
\hline Model & $\mathbf{R}$ & $\begin{array}{c}\mathbf{R} \\
\text { Square }\end{array}$ & Adj. R Square & $\begin{array}{c}\text { Std. Error } \\
\text { of the } \\
\text { Estimate }\end{array}$ \\
\hline 1 & $.683(a)$ & .466 & .462 & 6.379 \\
\hline
\end{tabular}

a Predictors: (Constant) Organizational Structure

b Dependent Variable: Teacher Performance

$\mathrm{R}$ Square figure at table 3 which means the coefficient of determination shows 0.466 or equal to $46.6 \%$. This figure means that $46.6 \%$ of the organizational structure has an effect on teacher performance, while $53.4 \%$ is influenced by other things. The Standard of Error of the Estimate (SEE) result is 6.379 for organizational structure variables. This shows that the organizational structure can be used as a tool for performance appraisal.

TABLE IV. DETERMINATION COEFFICIENT

\begin{tabular}{|c|c|c|c|c|c|c|}
\hline \multirow[t]{2}{*}{ Model } & & \multicolumn{2}{|c|}{$\begin{array}{l}\text { Unstandardized } \\
\text { Coefficients }\end{array}$} & \multirow{2}{*}{$\begin{array}{c}\begin{array}{c}\text { Stand. } \\
\text { Coeffici } \\
\text { ents }\end{array} \\
\\
\text { Beta } \\
\end{array}$} & \multirow[t]{2}{*}{$\mathbf{T}$} & \multirow[t]{2}{*}{ Sig. } \\
\hline & & $\mathrm{B}$ & $\begin{array}{l}\text { Std. } \\
\text { Error }\end{array}$ & & & \\
\hline \multirow[t]{2}{*}{1} & (Constant) & 25.126 & 6.554 & & 3.834 & .000 \\
\hline & $\begin{array}{c}\text { Org. } \\
\text { structure }\end{array}$ & .753 & .073 & .683 & $\begin{array}{r}10.27 \\
5\end{array}$ & .000 \\
\hline
\end{tabular}

a Dependent Variable: Teacher Performance

Table 4 about coefficients is intended to describe the regression coefficients. Knowing the regression coefficient of the researcher can illustrate the impact of the organizational structure on teacher performance.

Regression equations is $\mathrm{Y}=\mathrm{a}+\mathrm{b} \mathrm{x}_{2}$. Where $\mathrm{Y}$ is teacher performance, $\mathrm{x}$ is the organizational structure, $\mathrm{a}$ is the constant number of Unstandardized Coefficient which in this study amounted to 25.126. and $\mathrm{b}$ is the regression coefficient number value is 0.753 . Thus, the regression equation becomes $\mathrm{Y}=$ $25,126+0,753 \mathrm{x}$. This equation means that a constant of 25.126 if $\mathrm{x}$ is zero, then $\mathrm{Y}$ value is 25.126 and every increase of 1 unit of $\mathrm{X}$, will be followed by an increase in $\mathrm{Y}$ of 0.753 at a constant of 25.126 .

T-test is used to test the significance constants. Organizational structure variables are used as predictors of teacher performance variables. T-count in table 4 shows the numbers 10.275 and t table at the significance of $\alpha=0.05$ and DF $123-2=121$ produces 1.979 it means that $t$ count bigger than $t$ table $(10.275>1.979)$. Thus reject the null hypothesis, meaning that the regression coefficient is significant.
From several tests of correlation, regression, the coefficient of determination, and t-test shows a significant correlation between organizational structure with teacher performance. The correlation is strong, so it can influence teacher performance in Pesantren.

Theoretically, the relationship between organizational structure and performance is expressed by Robbins and Judge (2007) and Colquitt et. al (2009) which states the structural designs can effect or give influence to individual performance, and also empirically as described by Hutabarat (2015).

This research shows a result that a good organizational structure has a correlation with teacher performance in Pesantren. Therefore, the managers and leaders of educational institutions must build a good and appropriate organizational structure. Because this program can help to improve the teacher performance in educational institutions. In this case Pesantren, there is evidence of this.

The second hypothesis is there is correlation between organizational culture with teacher performance in Pesantren. After collected data and analyze it, found the data at table 5.

Table 5 show the strength of relationship between teacher performance and organizational culture variables. The result in Pearson correlation coefficient number is .749**. This means that the correlation between the teacher performance and organizational culture variables is 0.749 or a strong correlation because it is near to 1 . The two-star sign $(* *)$ means that the correlation is significant at number 0.01 and has a two-way (2tailed) possibility.

TABLE V. CORRELATION

\begin{tabular}{|c|c|r|r|}
\hline & & $\begin{array}{c}\text { Teacher } \\
\text { Performance }\end{array}$ & $\begin{array}{c}\text { Org. } \\
\text { Culture }\end{array}$ \\
\hline Teacher Performance & Pearson Correlation & 1 & $.749(* *)$ \\
Org. Culture & Sig. (2-tailed) &. & .000 \\
& Pearson Correlation & $.749(* *)$ & 1 \\
& Sig. (2-tailed) & .000 &. \\
\hline
\end{tabular}

** Correlation is significant at the 0.01 level (2-tailed).

The relationship between these two variables shown by result of the correlation is 0.000 that smaller than $0.001(0.000$ $<0.001)$. It's mean that the relationship between these variables is significant. Other values have two way (2-tailed), it's mean can be unidirectional or unidirectional. Thus reject the null hypothesis and accept alternative hypothesis, it's meaning there is a significant relationship between organizational culture and teacher performance in Pesantren.

Table 5 above shows the direction of the correlation between two variables, the direction is positive with the results of 0.749 . Thus it can be understood that the correlation of two variables is unidirectional.

The coefficient of determination between the organizational culture with teacher performance can be shown in table 6 Model Summary (b). It is to know the coefficient determination result between dependent and independent variables. 
TABLE VI. MODEL SUMMARY

\begin{tabular}{|c|c|r|r|r|}
\hline Model & R & R Square & \multicolumn{1}{|c|}{$\begin{array}{l}\text { Adj. R } \\
\text { Square }\end{array}$} & $\begin{array}{c}\text { Std. Error of the } \\
\text { Estimate }\end{array}$ \\
\hline 1 & $.749(\mathrm{a})$ & .561 & .557 & 5.785 \\
\hline
\end{tabular}

a Predictors: (Constant) Organizational Culture

b Dependent Variable: Teacher Performance in Pesantren

The R Square has the meaning as the coefficient of determination which shows 0.561 or equal to $56.1 \%$. This number means that $56.1 \%$ of organizational culture has an effect on teacher performance, while $43.9 \%$ are influenced by other things. The magnitude of the Standard Error of the Estimate (SEE) is 5.785 it shows that organizational culture variables can be used as predictors for performance assessment.

From table 7 about coefficient between organizational culture and teacher performance can be described the regression equations is $\mathrm{Y}=\mathrm{a}+\mathrm{b} \mathrm{x}$. Where $\mathrm{Y}$ is teacher performance, $\mathrm{x}$ is the organizational culture, $\mathrm{a}$ is the constant number of Unstandardized Coefficient which in this study amounted to 29.328. and $\mathrm{b}$ is the regression coefficient number value is 0.672 . Thus, the regression equation becomes $\mathrm{Y}=$ $29.328+0,672 \mathrm{x}$.

TABLE VII. COEFFICIENT

\begin{tabular}{|r|c|r|r|r|r|r|}
\hline $\begin{array}{r}\text { Mo } \\
\text { del }\end{array}$ & & \multicolumn{2}{|c|}{$\begin{array}{c}\text { Unstandardized } \\
\text { Coefficients }\end{array}$} & $\begin{array}{c}\text { Standardized } \\
\text { Coefficients }\end{array}$ & \multicolumn{1}{c|}{$\mathrm{t}$} & Sig. \\
\hline & & \multicolumn{1}{c|}{ B } & Std. Error & Beta & & \\
\hline 1 & $\begin{array}{c}\text { (Constant) } \\
\text { Org. } \\
\text { Culture }\end{array}$ & 29.328 & 5.086 & & 5.766 & .000 \\
& .672 & .054 & .749 & 12.429 & .000 \\
\hline
\end{tabular}

a Dependent Variable: Teacher Performance

This equation means that a constant of 29.328 if $\mathrm{x}$ is zero, then $\mathrm{Y}$ value is 29.328 and every increase of 1 unit of $\mathrm{X}$, will be followed by an increase in $\mathrm{Y}$ of 0.672 at a constant of 29.328 .

Another test for the inferential statistic is t-test, organizational culture are used as predictors for teacher performance. T-count as in table 7 shows the result 12.429 , and with significance $\alpha=0.05$ and DF $123-2=121$, has result 1.979. Then, t-count is bigger than t-table (12.429> 1.979). It's mean that regression coefficient is significant.

From several tests of correlation, the coefficient of determination, and t-test shows a significant correlation between organizational culture with teacher performance. The correlation is strong, so it can influence teacher performance in Pesantren.

As described on the theoretical framework above Daft (2007), Gibson et.al (2009), Robbins and Judge (2007), Suharsaputra (2013), Lunenburg and Ornstein (2004) stating that organizational culture influences employee performance. In this case, the theory and concept examined in educational institutions to Pesantren teacher. Empirically the study by Hutabarat (2015), Raza et al (2010), Koesmono (2005), Arifin et.al (2014), Ate (2014), Susilo and Supardjo (2014), explains that organizational culture influences employee performance. This research proves the correlation between the organizational culture with teacher performance in Pesantren.
The third proposed hypothesis is a significant relationship between organizational structure and organizational culture simultaneously with the teacher performance in Pesantren. To find out the magnitude of variability from the dependent variable in this case, is teacher performance which is explained using independent variables. Also, to calculate the magnitude of the role or the effect of the independent variable on the dependent variable the researcher uses the Summary Model. Analysis of the data obtained is as in table 8 .

\section{TABLE VIII. CORRELATION}

\begin{tabular}{|c|c|r|r|r|}
\hline Model & R & R Square & $\begin{array}{c}\text { Adj. R } \\
\text { Square }\end{array}$ & $\begin{array}{c}\text { Std. Error of } \\
\text { the Estimate }\end{array}$ \\
\hline 1 & $.764(\mathrm{a})$ & .584 & .577 & 5.654 \\
\hline
\end{tabular}

a Predictors: (Constant), organizational structure, organizational culture

b Dependent Variable: teacher performance

In multiple linear regression, $\mathrm{R}$ result is 0.764 , it shows multiple correlations (organizational culture and organizational structure) with teacher performance. Whereas R Square in the table above is equal to 0.584 . The $\mathrm{R}$ Square number is basically between $0-1$, and if the smaller the size of $\mathrm{R}$ Square, the weaker relationship between the two variables. But what the researchers found R Square or terminated coefficient is the amount of 0.584 or equal to $58.4 \%$. This means that $58.4 \%$ of teacher performance can be explained using organizational culture and structure variables, the remaining $41.6 \%$ is another factor.

The Standard Error of the Estimate (SEE) value in the table is 5.654. Thus it has meant that the independent variables of organizational culture and structure are valid to be used as predictors for teacher performance in Pesantren.

Next table 9 shows the ANOVA table. Which researcher used to find out the probability number, the result is:

TABLE IX. COEFFICIENT

\begin{tabular}{|c|c|c|r|r|r|l|}
\hline Model & & $\begin{array}{c}\text { Sum of } \\
\text { Squares }\end{array}$ & \multicolumn{1}{c|}{ Df } & \multicolumn{1}{c|}{$\begin{array}{c}\text { Mean } \\
\text { Square }\end{array}$} & \multicolumn{1}{c|}{ F } & \multicolumn{1}{c|}{ Sig. } \\
\hline 1 & Regression & 5381.959 & 2 & 2690.979 & 84.169 & $.000(\mathrm{a})$ \\
\hline & Residual & 3836.545 & 120 & 31.971 & & \\
\hline & Total & 9218.504 & 122 & & & \\
\hline
\end{tabular}

a Predictors: (Constant), organizational structure, organizational culture

b Dependent Variable: Teacher Performance

ANOVA calculations show the magnitude of the probability and significant result, which is used to test the feasibility of a regression model with a good probability number. To use as a regression model is must be smaller than 0.05. ANOVA test produces $\mathrm{F}$ number of 84.169 with a significance level (probability number) 0.000 . It's mean 0.000 smaller than $0.005(0.000<0.005)$ it's mean this regression model is feasible and significant to use in predicting teacher performance.

Based on ANOVA table also, the result of $\mathrm{F}$ table with the provisions of $\alpha$ : 0.05, and Degree of Freedom (df) Vector 1: number of variables - 1 so that it becomes $3-1=2$. And Vector 2 Number of respondents - Number of variables, in this case $123-2=121$ with these conditions obtained $F$ value from 
the table of 3.07. The result of F count from Anova table is 84,169 it's meant $\mathrm{F}$ count is bigger than F table $(84.169>$ 3.07). From this result can be concluded that organizational structure and culture affect teacher performance in Pesantren.

TABLE X. COEFFICIENT

\begin{tabular}{|c|c|c|c|c|c|c|}
\hline \multirow[t]{2}{*}{ Model } & & \multicolumn{2}{|c|}{$\begin{array}{l}\text { Unstandardized } \\
\text { Coefficients }\end{array}$} & \multirow{2}{*}{$\begin{array}{c}\begin{array}{c}\text { Standardi } \\
\text { zed } \\
\text { Coefficie } \\
\text { nts }\end{array} \\
\\
\text { Beta }\end{array}$} & \multirow[t]{2}{*}{$\mathrm{t}$} & \multirow[t]{2}{*}{ Sig. } \\
\hline & & B & $\begin{array}{l}\text { Std. } \\
\text { Error }\end{array}$ & & & \\
\hline \multirow[t]{3}{*}{1} & (Constant) & 21.400 & 5.845 & & 3.661 & .000 \\
\hline & $\begin{array}{l}\text { Org. } \\
\text { Culture }\end{array}$ & .498 & .085 & .556 & 5.829 & .000 \\
\hline & $\begin{array}{c}\text { Org. } \\
\text { Structure }\end{array}$ & .271 & .105 & .246 & 2.579 & .011 \\
\hline
\end{tabular}

a Dependent Variable: Teacher Performance

From table 10 about coefficient between organizational structure, organizational culture, with teacher performance can be described the regression equations is $Y=a+b_{1} x_{1}+b_{2} x_{2}$ Where $Y$ is the teacher performance, $x_{1}$ is the organizational culture, and $x_{2}$ is the organizational structure. $a$ is the constant number of Unstandardized Coefficient which in this study amounted $21.400, b_{1}$ is the regression coefficient number value is $0.498 . b_{2}$ is the regression coefficient number value is 0,271 . Thus the regression equation becomes $\mathrm{Y}=21.400+0,498 \mathrm{x}_{1}+$ $0,271 \mathrm{x}_{2}$.

This equation means that a constant of 21.400 if $\mathrm{x}$ is zero, then $\mathrm{Y}$ value is 21.400 and every increase of 1 unit of $\mathrm{x}_{1}$ and $\mathrm{x}_{2}$, will be followed by an increase in $\mathrm{Y}$ at a constant of 29.328 .

Another test for the inferential statistic is t-test, organizational culture are used as predictors for teacher performance. T-count as in table 10 shows the result 5.829 , and with significance $\alpha=0.025$ and DF $123-2=121$, has result 2.269. Than, $\mathrm{t}$-count is bigger than table $(5.829>$ 2.269). It's mean that the regression coefficient is significant. While t-count for organizational culture is 2.579 , it's mean bigger than t-table $(2.579>2.269)$. It's mean the regression coefficient is also significant.

About the relation between organizational culture and organizational structure with teacher performance Colquitt et. al (2009) and Robbins and Judge (2007) stated that organizational mechanisms consisting of culture and organizational structure are related individual performance.

\section{CONCLUSION}

Based on the results can be concluded that there is a relationship between organizational structure and teacher performance in Pesantren, the relation is significant with result 0.683 . Besides that, the organizational structure contributes $46.6 \%$ through the linear regression equation $\mathrm{Y}=25.126+$ $0.753 \mathrm{X} 2$ which is significant at the alpha level of 0.05 . This means that to improve teacher performance, the organizational structure can be used as an effective tool and cannot be ignored.
The relationship between organizational culture and teacher performance also positive and significant relationship. The higher organizational culture of the Pesantren institution, the higher teacher performance in it. The correlation result is 0.749. Besides that, organizational culture contributes $56.1 \%$ through the linear regression equation $\mathrm{Y}=29,328+0,672 \mathrm{X} 1$ which is significant at the alpha level 0,05 . With these contributions, it means that in order to improve teacher performance, organizational culture can be used as an effective tool and cannot be ignored

The relationship between organizational culture and organizational structure simultaneously on the teacher performance in Pesantren is positive and significant. The higher both of independent variabel, the higher teacher performance in it. Organizational culture and organizational structure are positively and significantly related to the performance of pesantren teachers in the city of Depok with a correlation coefficient of 0.764. Apart from that, these two variables contribute $58.4 \%$ through the linear regression equation $\mathrm{Y}=21,400+0,498 \mathrm{X} 1+0,271 \mathrm{X} 2$ which is significant at the alpha level 0,05 . This means that to improve teacher performance, organizational culture and organizational structure can be used as an effective tool.

\section{ACKNOWLEDGMENT}

I would like to thank Allah Swt., family, friends, teachers, staff and the lecturers in Universitas Ahmad Dahlan for extremely helpful and better support for this research and publication. Also to the organizers who have allowed mo to join this agenda.

\section{REFERENCES}

[1] Colquit, LePine, Wesson, Organizational Behavior, Improving Performance and commitment in the workplace, New York: McGraw Hill International Edition, 2009.

[2] Dewi Hangggraeni, Manajemen Sumber Daya Manusia, Jakarta; FEUI, 2012

[3] Dewi Hanggraeni, Perilaku Organisasi Teori, Kasus, dan Analisis, Jakarta: Lembaga Penerbit FEUI, 2011.

[4] Freddy Arifin, Eka Annan Troena, Djumahir, dan Mintarti Rahayu, "Organizational Culture, Transformational Leadership, Work Engagement and Teacher Performance; Test of Model”, International Journal of Education and Research, Vol. 2, No. 1. Jan. (2014). p. 1-14

[5] H. John Bernardin dan Joyce E.A. Russel, Human Resource Management: an experimental approach, (New York: McGraw-Hill, 1993)

[6] Husaini Usman, MANAJEMEN Teori, Praktik, dan Riset Pendidikan, Cet.ke-3., Jakarta: Bumi Aksara, 2011.

[7] James L. Gibson, John. M Ivancevich, James H. Donelly Jr, and Robert Konopaske, Organizations: Behavior, Strutcture, Processes, Eleventh Edition New York: Mc Graw Hill, 2004.

[8] Made Pidarta, Manajemen Pendidikan Indonesia, Jakarta: Rineka Cipta, 2011.

[9] Madyo Eko Susilo dan Soepardjo, "Faktor Dominan yang Mempengaruhi Motivasi Kerja, Kinerja, dan Kepuasan Kerja Guru SMA", Jurnal Ilmu Pendidikan, Vol. 20, No. 2, (2014). p. 134

[10] Muhaimin, Suti'ah, dan Sugeng Listyo Prabowo, Manajemen Pendidikan Aplikasinya dalam Penyusunan Rencana Pengembangan Sekolah/Madrasah, Jakarta: Kencana, 2011

[11] Paulus Mikku Ate, "Budaya Organisasi Sekolah dalam Meningkatkan Kinerja Guru”, Jurnal Pendidikan Humaniora, Vol. 2, No. 4, (2014), p. 391-400 
[12] Richard L. Daft. Understanding The Thory and Design of Organizations, Vanderbilt University Thomson South Western. 2007

[13] Robert L. Mathis and John H. Jackson, Human Resources Management, Jakarta: Salemba Empat, 2006

[14] Stephen P. Robbins \& Timothy A. Judge, Organizational Behavior, Twelfth Edition. New Jersey: Pearson Education, Inc. 2007.

[15] Steven L. Mc Shane \& Mary Ann Von Glinow, Organizational Behavior Emerging Realities for the Workplace Revolution, New York: Mc Graw Hill Irwin, $\mathrm{tt}$

[16] Syed Ahmad Reza dan Pir Mehr Ali Shah, "Impact of Organizational Climate on Performance of College Teachers in Punjab", Journal of College Teaching \& Learning, Vol. 7, No. 10, (Oct). (2010), p. 47-52

[17] Tabrani Rusyan dan Wasmin, Etos Kerja Dalam Meningkatkan Produktivitas Kinerja Guru, Jakarta: Intimedia, 2008.

[18] Teman Koesmono, "Pengaruh Budaya Organisasi Terhadap Motivasi dan Kepuasan Kerja Serta Kinerja Karyawan Pada Sub Sektor Industri Pengolahan Kayu Skala Menengah di Jawa Timur", Jurnal Manajemen dan Kewirausahaan, Vol. 7. No. 2. (Sep). (2005). p. 162-179

[19] Wesly Hutabarat, "Dampak Budaya Organisasi, Struktur Organisasi, dan Kepuasan Kerja Terhadap Kinerja Guru SMA", Cakrawala Pendidikan, No. 3 (2015). p. 412-420

[20] Wesly Hutabarat, "Do Organizational Structure and Organizational Culture Affect Teachers' Work Motivation to Some Extent", International Journal of Sciences; Basic and Applied Research, Vol. 20 , No. 2, (2015) p. 350-362

[21] Wesly Hutabarat, "Investigation of Teacher Job-Performance Model: Organization Culture, Work Motivation and Job-Satisfaction", Asian Social Sciencei, Vol. 11. No. 18. (2015) p. 295-304 